\title{
Global World Wide Rating Systems Development and Implementation Guidelines
}

\author{
Ahmed Gomaa ${ }^{1,2}$ \\ ${ }^{1}$ Department of Civil Engineering, Faculty of Engineering, Alexandria University, Egypt \\ ${ }^{2}$ Environmental Engineering Department, International Virtual University, UK
}

Copyright $\odot 2018$ by authors, all rights reserved. Authors agree that this article remains permanently open access under the terms of the Creative Commons Attribution License 4.0 International License

\begin{abstract}
As world population continues to expand, implementation of resource-efficient measures in all areas of human activity is imperative. The purpose of this research is to examine the history of Sustainable Building, main factors and categories and to provide a guideline for countries, parties and/or foundation interested in developing a Green Building rating systems. Various Green Building rating systems, their components, scoring system and main categories were discussed. It was found that, factors related to the economic dimension pillar was considered most followed by factors related to social dimension and the environmental dimension had the least intension from developers. The main goal of the study is not to rectify this action in rating system but to encourage rating system developers to choose the convenient to their specific cases and local conditions and to proceed with establishing a sustainable rating system. The research also invites the developers to balance the three sustainability pillars (Environmental, Economic and social) in their proposed systems.
\end{abstract}

Keywords Green Building, Economic, Environmental and Social Dimensions, Sustainability Pillars, Pollution, Energy

\section{Introduction}

The first role of sustainability is to preserve "natural capital" especially soil, air and water on which life depends. In addition to use the concept of "natural income" which is the resources, that nature replaces daily in large quantities like solar energy, wind and waterpower.

The second role of sustainability is to eliminate the release of toxic materials due to our activities, based on those two concepts the idea of sustainable buildings start to appear known as Green Building.

\subsection{Objective}

Throughout the study of Green Building systems, it was noticed that some countries developed and implemented a sustainable (Green Building) rating systems and other countries either are in process or did not start yet. Classification related to Developed/Developing country was not a factor in implementing a sustainable rating system, as mentioned in the $17^{\text {th }}$ Annual Pacific Rim Real Estate Society Conference, Gold Coast [1].

The aim of this paper is to provide guidelines for countries, parties or foundation interested in developing a rating system by summarizing the most popular Green Building rating systems to help countries and organizations to develop their own systems based on the given data. In addition, to highlight areas required to be considered when developing a rating system. The main intention of this paper is not to show the difference in various rating systems but to show the common areas among them.

\section{Literature Review}

\subsection{Green Buildings Pillars}

Green Building is a phrase that is used a lot; "Green" is a term refers to environmentally friendly practices. Green Building is a whole system approach to the design, structure and operation of building from the early stages of development through the final finishes. In addition, Green Building is defined by the Federal Commitment to Green Building [2] as the practice of

1. Increase the efficiency of which buildings and their sites use energy, water and materials

2. Reduce building impacts of human health and environment through better sitting, design, construction, operation, maintenance and removal throughout the complete life cycle.

Kohler [3] referred to both a sustainable and green building and categorizes them into three dimensions of sustainability: Environmental, economic and social \& Cultural sustainability. 


\subsubsection{Environmental Dimension}

There are two major ways to reduce negative human impact and enhance ecosystem services; the first of these is Environmental Management. This direct approach is based largely on information gained from earth science, environmental science and conservation biology. The second approach is through Demand Management of human resource use.

Management of human consumption of resources is an indirect approach based largely on information gained from economics. This impact is reduced not only by consuming less but also by making the full cycle of production, use and disposal more sustainable.

\subsubsection{Economic Dimension}

Sustainability economics represents "a broad interpretation of ecological economics where environmental and ecological variables and issues are basic but part of a multidimensional perspective. Social, cultural, health-related and monetary/financial aspects have to be integrated into the analysis. However, the concept of sustainability is much broader than the concepts of sustained yield of welfare, resources, or profit margins. At present, the average per capita consumption of people in the developing world is sustainable but population numbers are increasing and individuals are aspiring to high-consumption Western lifestyles. The developed world population is only increasing slightly but consumption levels are unsustainable.

\subsubsection{Social Dimension}

Sustainability issues are generally, expressed in scientific and environmental terms, but implementing change is a social challenge that entails, among other things, international and national law, urban planning and transport, local and individual lifestyles and ethical consumerism, human rights and human development, corporate power and environmental justice, global poverty and citizen action.

\subsection{Main Considerations of Green Building}

Because of the complexity of setting green building measures, Tom Woolley, Sam Kimmins, Paul Harrison and Rob Harrison [4], found it useful to group consideration of green building under four headings as following:

\subsubsection{Reducing Energy in Use}

By using maximum possible low embodied energy insulation, but with good ventilation, using low energy lighting and electrical appliances, using efficient low pollution heat, making use of passive and active solar energy wherever feasible, using passive and natural ventilation systems rather than mechanical and by proper positioning for buildings to maximize the utilization of natural solar lighting and natural ventilation

\subsubsection{Minimizing External Pollution and Environmental Damage}

Establishing design in harmonious relationship with the surroundings, avoiding destruction of natural habitats, re-using rainwater on site, treating and recycling waste water on site if possible, trying to minimize extraction of materials unless good environmental controls exist and avoiding materials which produce damaging chemicals as a byproduct and not to use dump waste material off site but re-use on site.

\subsubsection{Reduce Embodied Energy and Resource Depletion}

Using locally sourced materials, using material found on site, minimizing the use of imported materials, using material from sustainably managed sources, keeping use of materials from non-renewable sources to a minimum, using low energy materials, keeping high embodied energy materials to a minimum, using second hand/recycled materials where appropriate and re-using existing buildings and structures instead of always assuming that new buildings are required

\subsubsection{Minimize Internal Pollution and Damage to Health}

Using nontoxic materials or low emission materials, avoiding fibers from insulation materials getting into atmosphere, ensuring good natural ventilation, reducing dust and allergens, reducing impact of electromagnetic fields, creating positive character in the building and relationship with site and involving users in design and management of building and evaluating environmental choices.

\section{Green Building Categories and Rating Systems}

\subsection{Green Building Categories}

There are nine main categories, in general as advised by the Technical Guide of Code for Sustainable Homes [5], covering Green Buildings' codes. Those categories are:

- Energy and $\mathrm{CO}_{2}$ Emissions

This category mainly deal with emission rates, energy efficiency, low and zero carbon technology.

- Water

This category mainly deal with indoor and external water use.

- Materials

This category mainly deal with environmental impact of materials, and responsible sourcing of materials.

- $\quad$ Surface water run-off

This category mainly deal with management of surface water run-off and flood risk.

- Waste

This category mainly deal with storage of non-recyclable waste and recyclable household 
waste, construction's site waste management and composing.

- Pollution

This category mainly deal with global warming potential and NOx emissions.

- Health and well-being

This category mainly deal with day lighting, sound insulation, private space and life time homes.

- $\quad$ Management

This category mainly deal with home user guide, construction site impacts and security.

- $\quad$ Ecology

This category mainly deal with ecological value of site, ecological enhancement, protection of ecological features and the change in ecological value of site.

Each category of the above includes a number of environmental issues; each issue is a source of environmental impact

\section{Globally Recognized Rating Systems}

\subsection{Green Building Rating Systems}

Candace Say and Antony Wood [6] mentioned many sustainable building performance rating systems to be considered, the first system for rating the sustainability of commercial buildings was LEED (Leadership in Energy and Environmental Design) it is presently considered to be the benchmark

\subsubsection{LEED - US Green Building Council}

The Leadership in Energy and Environmental design green building rating system program is a national consensus-based, market-driven building rating system designed to accelerate the development and implementation of green building practices. In short, it is a leading-edge system for designing, constructing and certifying the world's greenest and best buildings.

LEED works well because it is simple to understand, it is divided into five categories related to sitting, water conservation, energy, materials and indoor environmental quality, plus an innovation and design category according to Building Design \& Construction White Paper on Sustainability [7] and Greg Kats [8]. Each category contains a specific number of credits as following:

Table 1. LEED credit points

\begin{tabular}{|l|l|}
\hline Category & Possible points \\
\hline Sustainable sites & 26 \\
Water efficiency & 10 \\
Energy / atmosphere & 35 \\
Material / resources & 14 \\
Indoor environmental quality & 15 \\
Innovation & 6 \\
Regional priority & 4 \\
\hline Total & 110 \\
\hline
\end{tabular}

LEED system created certification levels based on possible points a project can earn, a project that earn minimum (40 points) can become a "LEED certified" on up the ladder to Platinum, LEED certificate levels are shown below:

Table 2. LEED certification levels

\begin{tabular}{|l|l|}
\hline LEED Rating & Earned Points \\
\hline Certified & $40-49$ \\
Silver & $50-59$ \\
Gold & $60-79$ \\
Platinum & 80 or more \\
\hline
\end{tabular}

\subsubsection{Energy Star - U.S. Department of Energy Program} for Products and Buildings

Colorado Springs utilities [9] described the Energy Star program as a joint program of the U.S. Environmental Protection Agency (EPA) and the U.S. Department of Energy (DOE). The focus of the ENERGY STAR program is energy, as the name implies. This system applies to existing functioning buildings not to buildings being designed or built. The basis of compliance is the electric and gas consumption, per square foot.

For new building designs, ENERGY STAR provides design guidance information that architects and engineers can use to steer the new design toward ENERGY STAR rating success, after the building is built, Portfolio Manager Software is used to track the energy used and after 12 months, the building can be rated.

\subsubsection{BREEAM - English and Canadian Green Building Systems}

Candace Say and Antony Wood [6] described BREEAM the program of the Building Research Establishment (BRE), an organization based in UK, and stands for the Building Research Establishment Environmental Assessment Method. BREEAM uses categorical assessment measures to evaluate the environmental performance of new and existing buildings. BREEAM also assesses best practices in environmental design and management in construction and property sectors.

BREEAM evaluates a range of building related categories such as:

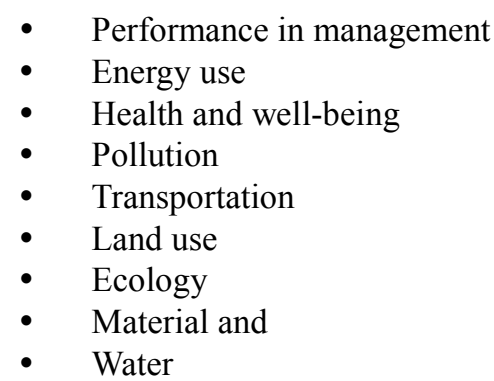

Each category is awarded "Credits" that are weighted and added together to generate a single score as follows: 
Table 3. BREEAM Points, system

\begin{tabular}{|l|l|}
\hline BREEAM rating & \% Score \\
\hline Unclassified & $<30$ \\
\hline Pass & $\geq 30$ \\
\hline Good & $\geq 45$ \\
\hline Very good & $\geq 55$ \\
\hline Excellent & $\geq 70$ \\
\hline Outstanding & $\geq 85$ \\
\hline
\end{tabular}

BREEAM provides professional review of environmental impact aspects of new construction or major remodeling projects, ideally during various stages of the building process.

\subsubsection{SPiRiT - U.S. Air Force Sustainability Standards}

Richard Schneider and Donald F. Fournier [10] and Richard Schneider [11] summarized the Sustainable Project Rating Tool (SPiRiT) which was developed by the U.S. Army Engineer Research and Development Center as a measurement system for rating new and major renovations to industrial buildings. It evaluates environmental performance from a whole building perspective over a building's life cycle and provides a definitive standard to assess the sustainability or "Green" attributes of the design-construct process for a given project.

SPiRiT addresses critical areas of the design-construct process for seven categories, which are:

- Site

- Water

- $\quad$ Energy usage

- Materials

- Indoor environment quality

- $\quad$ Facility delivery

- $\quad$ Current \& Future mission

The rating system consists of pre-requisitions and credits that when met provide points towards an overall score as following.

Table 4. SPiRiT Scoring System

\begin{tabular}{|l|l|}
\hline SPiRiT Rating & Score \\
\hline Bronze & $25-34$ \\
\hline Silver & $35-49$ \\
\hline Gold & $50-74$ \\
\hline Platinum & $75-100$ \\
\hline
\end{tabular}

Each credit has a defined intent and one or more requirements that must be met to garner the points. The overall score is used to indicate one of the four project certification levels as shown:

Table 4 SPiRiT Certification Levels

All Army Military Construction projects must achieve a Bronze rating level, projects selected as a showcase projects need to achieve a Gold or Platinum certification level.

\subsubsection{BCA Green Mark - Building and Construction Authority Singapore}

Building and Construction Authority (BCA) Green Mark Certification Standard for Existing Buildings [12] developed a scoring system sets out the minimum environmental sustainability standard for buildings and the administrative requirements. It has adopted the BCA Green Mark's criteria as the compliance method in assessing the environmental performance of a building development.

There are basically, two sets of criteria one for Residential Buildings and other for Non-Residential Buildings. The criteria consist of five environmental impact categories as follows:

- Energy Efficiency

- Water Efficiency

- Environmental Protection

- Indoor Environmental quality

- Green Features and Innovations

- Bonus Points (Renewable Energy)

These environmental impact categories are broadly classified under two main groups (I) Energy related requirements (Energy Efficiency) and (II) Other Green requirements (Water Efficiency, Environmental Protection, Indoor Environmental quality and Green Features and Innovations)

BCA Green Mark Award Rating is summarized as follows:

Table 5. BCA Award ratings

\begin{tabular}{|l|l|}
\hline Green Mark Rating & Score \\
\hline Green Mark Platinum & 90 and above \\
\hline Green Mark GoldPlus & 85 to $<90$ \\
\hline Green Mark Gold & 75 to $<85$ \\
\hline Green Mark Certified & 50 to $<75$ \\
\hline
\end{tabular}

4.1.6. CHPS - California Collaborative for High Performance Schools

Air Quality Sciences, Inc. [13] discussed the Collaborative for High Performance Schools (CHPS) which aims to increase the energy efficiency of schools by marketing information, services and incentive programs directly to schools districts and designers. Sustainable schools provide an environment conducive to learning and student achievement when saving money, energy, and resources. Sustainable schools have been shown to provide heightened student performance, reduced operation costs, better student and teacher health, increased average daily attendance and enhanced indoor and outdoor environmental impact

The CHPS certification criteria define a high performance school by addressing the following:

- $\quad$ Site planning

- Water efficiency 
- $\quad$ Energy efficiency

- Materials

- Indoor air quality

- District resolution.

CHPS is a pass/fail rating system for new buildings.

Projects must earn a minimum number of points for credits in specified categories (vary from a state to another) as well as comply with all the required pre-requisites, only new construction, major modernizations and new buildings on existing campuses are recognizes as CHPS schools.

\subsubsection{Go Green - Building owners \& Managers Association (BOMA BESt)}

Amy Vandervelde, Wendy Waters [14] and James Furlong [15] mentioned that original BOMA Go Green standard underwent significant improvement and was rebranded as BOMA BESt (BOMA Building Environmental Standards), to earn BOMA BESt certification, a building must comply with ten compulsory "Best Practices" if this is achieved, the building can be certified at a level of 1 through 4 depending on the score of the performance data submitted. Values (in points) of individual performance criteria are not provided to the user to minimize the opportunity for users to "chase points" but the score is automatically calculated by online tools. Certification levels for BOMA BESt as shown below:

Table 6. Go Green Scoring System

\begin{tabular}{|c|c|}
\hline Rating & Score \\
\hline Level 1 & Meet BOMA Go Green best practice \\
Level 2 & $70 \%-79 \%$ score on Go Green Plus Assessment \\
Level 3 & $80 \%-89 \%$ score on Go Green Plus Assessment \\
Level 4 & $90 \%+$ score on Go Green Plus Assessment \\
\hline
\end{tabular}

The ten compulsory Go Green Best Practices are summarized as follows:

- Reduction in Energy consumption

- Reduction in water usage

- Construction waste management

- Recycling

- Management of hazardous material

- Use of safe and recycled materials

- Management of Ozone depleting substances

- Indoor air quality

- HVAC maintenance

- Communication program

4.1.8. Estidama Pearl Rating System - Abu Dhabi Urban Planning Council (United Arab Emirates)

Pearl Building Rating Systems "Design and Construction" [16] Estidama, which means "Sustainability" in Arabic, aims to create more sustainable communities, cities and global enterprises by balancing four pillars of sustainability (Environment, Economy, Culture and Social)
Pearl rating system is organized into seven categories that are fundamental to more sustainable development. These categories are:

- Integrated development process (IDP)

- Natural system (NS)

- $\quad$ Livable buildings (LB)

- $\quad$ Precious water (PW)

- $\quad$ Resourceful energy (RE)

- $\quad$ Stewarding materials (SM)

- Innovating practices (IP)

Within each section, there are both mandatory and optional credits and credit points are awarded for each optional credit achieved. The pearl rating system is summarized as following:

Table 7. Estidama Pearl Rating System

\begin{tabular}{|l|l|}
\hline Requirement & Pearl Rating \\
\hline All mandatory credits & 1 Pearl \\
\hline All mandatory credits +60 credit points & 2 Pearl \\
\hline All mandatory credits +85 credit points & 3 Pearl \\
\hline All mandatory credits +115 credit points & 4 Pearl \\
\hline All mandatory credits +140 credit points & 5 Pearl \\
\hline
\end{tabular}

The number of credit points available in a given section determines the weighting of the section. Different section uses may have a different number of credit points for a particular component.

\subsubsection{QSAS - Qatar Sustainability Assessment System}

QSAS which now is known as GSAS, replacing the word Qatar by Gulf, has four pillars of sustainability (Environment, Economy, Social and Human Development). In March, 2011 the State of Qatar integrated QSAS into the Qatar Construction Specifications (QCS) making the implementation of certain criteria mandatory for buildings developed in Qatar.

The development of the rating system took advantage of a comprehensive review of combined best practices employed by a mix of established international and regional rating systems. This review has been performed while taking into consideration the needs that are specific to Qatar's local environment, culture, and policies. This has led to adaptations and additions to sustainability criteria. Measurements for the rating system are designed to be performance-based and quantifiable. The result is a performance-based sustainable building rating system customized to the unique conditions and requirements of the State of Qatar according to "GSAS Building Typologies Design Guidelines" [17].

Based on the result of the project review a final score and certification level will be given as follows: 
Table 8. QSAS Certification Levels

\begin{tabular}{|c|c|c|}
\hline Score & Certification level & QSAS certification \\
\hline $\mathrm{X}<0$ & - & Certification denied \\
\hline $0.0 \leq X \leq 0.5$ & $\begin{array}{l}* \\
\text { One star }\end{array}$ & \multirow{6}{*}{ Certification achieved } \\
\hline $0.5 \leq X \leq 1.0$ & $\begin{array}{l}* * \\
\text { Tow stars }\end{array}$ & \\
\hline $1.0 \leq X \leq 1.5$ & $\begin{array}{l}* * * \\
\text { Three stars }\end{array}$ & \\
\hline $1.5 \leq X \leq 2.0$ & $\begin{array}{l}* * * * \\
\text { Four stars }\end{array}$ & \\
\hline $2.0 \leq X \leq 2.5$ & $\begin{array}{l}* * * * * \\
\text { Five Stars }\end{array}$ & \\
\hline $2.5 \leq \mathrm{X} \leq 3.0$ & $\begin{array}{l}* * * * * * \\
\text { Six stars }\end{array}$ & \\
\hline
\end{tabular}

The assessment system consists of eight categories and 48 criteria; the following table summarizes the categories, their associated weights and the goal of each category

- Urban conductivity

- Site

- Energy

- Water

- Materials

- Indoor environment

- Culture and economic value

- Management and operation

\subsubsection{Green Star (Australia)}

The Green Building Council of Australia (GBCA) was established to develop a sustainable property industry and they established the Green Star rating system to reduce the environmental impact of buildings, fit outs and communities, improve occupant health and productivity and achieve cost savings as mentioned by Candace Say and Antony Wood [6] and Green Building Council of Australia [18].

Green Star rating tools are available for a variety of building types, including offices, public buildings, retail centers, schools and universities, hospitals, apartment buildings and industrial facilities.

Green Star certification is based on an independent assessment of sustainability outcomes against key impact criteria and is summarized as follows:

Table 9. GSA Certification Levels

\begin{tabular}{|l|l|l|}
\hline Score & Certification level & $\begin{array}{l}\text { GSA } \\
\text { certification }\end{array}$ \\
\hline $45-59$ & $\begin{array}{l}* * * * \\
\text { Four stars }\end{array}$ & Best Practice \\
\hline $60-74$ & $\begin{array}{l}* * * * * \\
\text { Five Stars }\end{array}$ & $\begin{array}{l}\text { Australian } \\
\text { Excellence }\end{array}$ \\
\hline $75-100$ & $\begin{array}{l}* * * * * \\
\text { Six stars }\end{array}$ & World Leadership \\
\hline
\end{tabular}

Green Star evaluates the environmental initiatives of projects against eight environmental impact categories:

- Management

- $\quad$ Energy efficiency

- Water efficiency
- Indoor environment quality

- Transport

- Materials

- $\quad$ Land use and ecology

- Emissions

- Innovation

\subsubsection{CASBEE}

Shuzo Murakami [19], Candace Say and Antony Wood [6] and Air Quality Sciences, Inc. [13] mentioned CASBEE as a relatively new system developed for the Japanese market and is available in English.

The system requires documentation of quantifiable sustainable design achievements, which are assessed by trained, first-class architects, which have passed the CASBEE assessor examination.

CASBEE major categories of criteria include the following:

\section{Building Environmental Quality and Performance}

- Indoor environment (noise and acoustics, thermal comfort, lighting and illumination, and air quality)

- Quality of services (functionality and usability, amenities, durability and reliability, flexibility and adaptability)

- Outdoor environment on site (preservation and creation of biotope, townscape and landscape, and outdoor amenities)

\section{Building Environmental Loadings}

- Energy (thermal load, use of natural energy, efficiency of systems, and efficient operations)

- Resources and materials (water conservation, recycled materials, sustainably harvested timber, materials with low health risks,

- $\quad$ Reuse and reusability, and avoidance of CFCs and halons)

- Off-site environment (air pollution, noise and vibration, odor, sunlight obstruction, light pollution, heat island effect, and local on local infrastructure)

CASBEE scoring system uses a more complex approach; it places the above-mentioned two categories to determine the building environmental efficiency as a ratio of them.

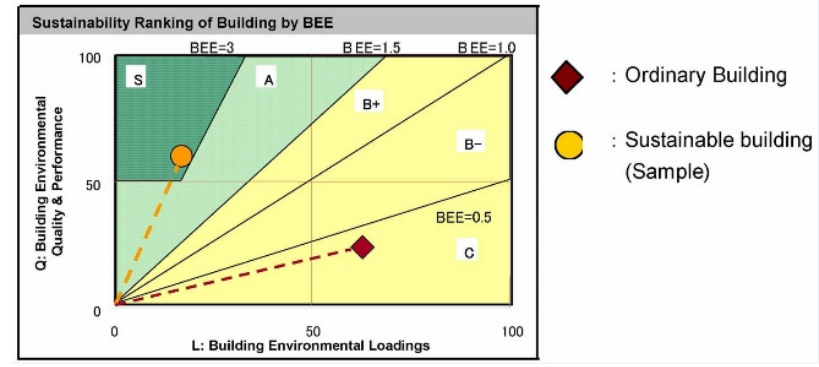

Figure 1. CASBEE Scoring System 


\subsubsection{Green Globes}

Candace Say and Antony Wood [6] and Air Quality Sciences, Inc. [13] mentioned Green Globes as a system developed using the Building Research Establishment's Environmental Assessment Method (BREEAM). Projects are awarded points based on their performance in seven areas of assessment in the New Construction module and six in the Existing Building module.

Green Globes uses the following categories:

- Site selection

- Water

- Energy use

- Transportation

- Materials and resources

- Indoor quality

- Management

The final score of Green Globes is based on the sum of point of each category and a third party certification is required to formally complete the process.

Table 10. Green Globes Certification Levels

\begin{tabular}{|l|l|}
\hline Level & Score of total points \\
\hline One & $35 \%-54 \%$ \\
\hline Two & $55 \%-69 \%$ \\
\hline Three & $70 \%-84 \%$ \\
\hline Four & $85 \%-100 \%$ \\
\hline
\end{tabular}

\subsubsection{Green Star South Africa}

The Green Building Council of South Africa [20] developed a sustainable a rating based on Australia's Green Star system.

The objectives of (GSSA) are to establish a common language and standard of measurers for green buildings, promote integrated building design, raise awareness, reduce environmental impact and recognize environmental leadership.

Green Star certification assessment of sustainability outcomes against key impact criteria and is summarized as follows:

Table 11. GSSA Certification Levels

\begin{tabular}{|c|l|l|}
\hline Score & Certification level & $\begin{array}{l}\text { GSSA } \\
\text { certification }\end{array}$ \\
\hline $45-59$ & $\begin{array}{l}* * * * \\
\text { Four stars }\end{array}$ & Best Practice \\
\hline $60-74$ & $\begin{array}{l}* * * * * \\
\text { Five Stars }\end{array}$ & $\begin{array}{l}\text { Australian } \\
\text { Excellence }\end{array}$ \\
\hline $75-100$ & $\begin{array}{l}* * * * * \\
\text { Six stars }\end{array}$ & $\begin{array}{l}\text { World } \\
\text { Leadership }\end{array}$ \\
\hline
\end{tabular}

Green Star evaluates the environmental initiatives of projects against eight environmental impact categories:

- Management

- $\quad$ Energy efficiency

- Water efficiency
- Indoor environment quality

- Transport

- Materials

- $\quad$ Land use and ecology

- Emissions

- Innovation

\section{Results and Discussion}

Arranging all factors discussed in a table, giving each component an equal weightage and calculating mathematically the percentage of contribution of each factor in the overall rating system process, it was noted that elements related to Energy, Water and Materials contributed around $50 \%$ of the rating system. Although factors related to pollution, waste did not have more focus, and their contribution in rating system was less that $5 \%$.

Below table shows the percentage of contribution of each main Green Building requirement as per the studied systems.

Table 12. Factor contributing Green Building Requirements

\begin{tabular}{|c|c|c|}
\hline Ser. & Category & \% age \\
\hline 1. & Energy and $\mathrm{CO}_{2}$ Emissions & $19 \%$ \\
\hline 2. & Water & $13 \%$ \\
\hline 3. & Materials & $15.5 \%$ \\
\hline 4. & Waste & $1 \%$ \\
\hline 5. & Pollution & $3.5 \%$ \\
\hline 6. & Health \& Well being & $13 \%$ \\
\hline 7. & Management & $10.5 \%$ \\
\hline 8. & Ecology & $17.5 \%$ \\
\hline 9. & Others & $7 \%$ \\
\hline
\end{tabular}

The analysis of the Factor contributing Green Building Requirements showed that Energy, Material and Ecology had the highest focus all over various rating systems; those factors have direct impact on the economic pillar due to either fuel prices or material and land prices.

Health \& Well-being, water and Management had intermediate involvement and a closer look to those factors shows that they are related to society pillar. Environmental related pillars had the least focus on rating systems.

Innovation and other exceptional performance factors were addressed higher than Environmental factors.

\section{Conclusions}

Figure 2 illustrates the main Green Building requirements and their implementation percentage sorted from high to low. 
Factor contributing Green Building Requirements

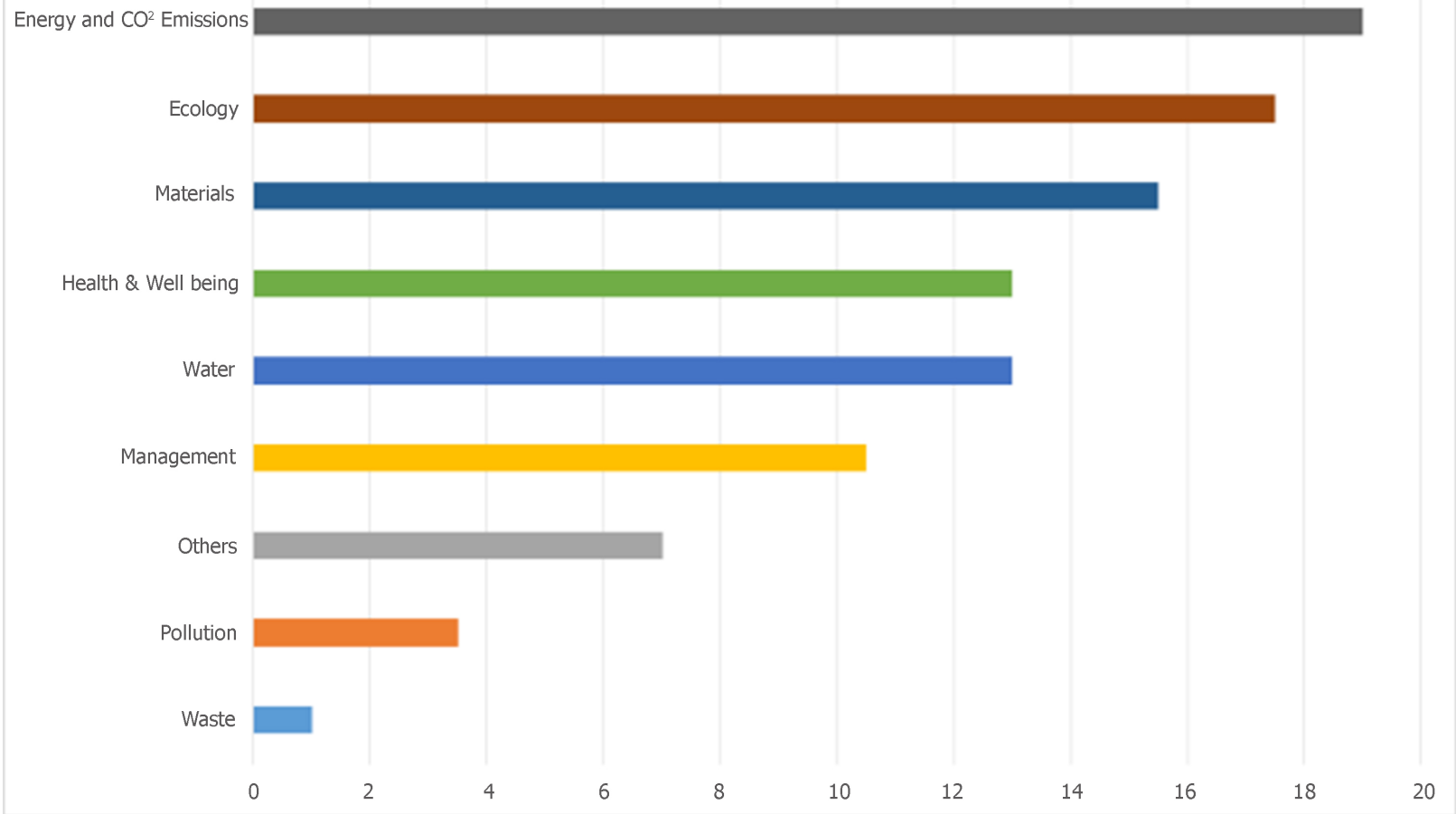

Figure 2. Factor contributing Green Building Requirements

The study is a modest contribution to parties planning to develop a sustainable rating system by drawing the main Guideline in the picture of sustainability factors used around the world. Implementing Sustainability requirements needs commitment from all involved parties as well as incentives from authorities.

The study shows that factors related to social and economic pillar are well taken into consideration. It is important to address to developers intend to develop Green Building rating system the importance of Environmental factors (Pollution and Waste) and the need to balance the three pillars.

The pollution factor may include Carbon footprint reduction, dust control systems, sewage treatment, industrial and chemical pollutants, vapor recovery systems and similar factors.

The waste factor my include construction and demolition waste, medical and clinic wastes, gray water, organics and similar items.

Innovation always could be considered as a personalize engine to any created Rating system which may could improve the sustainability philosophy to suit the local conditions and needs of the certain country. 
Factor contributing Green Building Requirements:

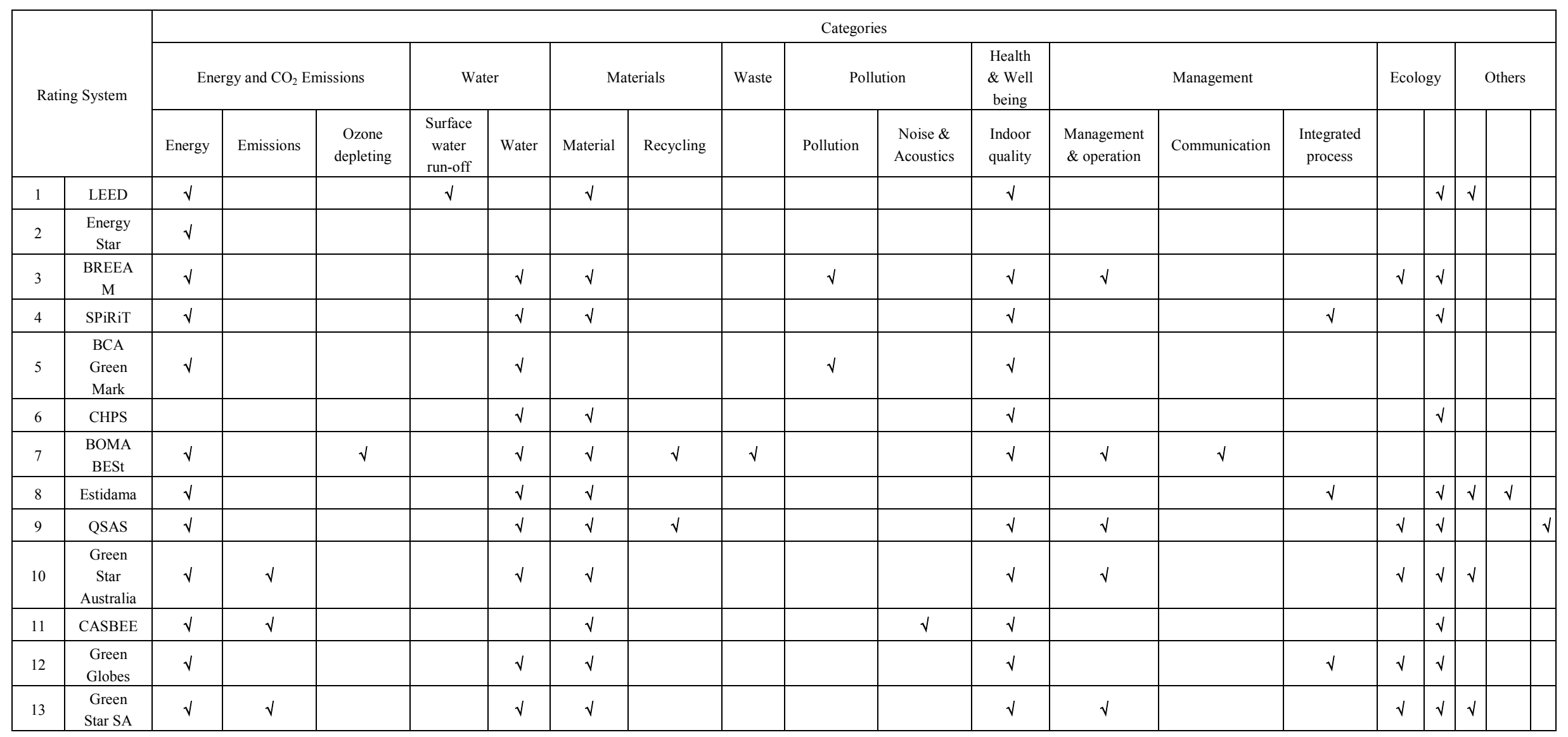




\section{REFERENCES}

[1] A Comparison of International Sustainable Building Tools An Update. The 17th Annual Pacific Rim Real Estate Society Conference, Gold Coast 16-19 January 2011

[2] Federal Commitment to Green Building: Experiences and Expectations -2008

[3] The relevance of Green Building Challenge: an observer's perspective. Building Research \& Information - Niklaus Kohler -1999

[4] "Green Building Handbook - Volume 1 A guide to building products and their impact on the environment" - Tom Woolley, Sam Kimmins, Paul Harrison and Rob Harrison 2011

[5] Code for Sustainable Homes Technical Guide -Department for Communities and Local Government, UK - 2010

[6] Sustainable rating systems around the world - Candace Say and Antony Wood - 2008

[7] Building Design \& Construction White Paper on Sustainability - 2003

[8] "The cost and financial benefits of Green Building" Greg Kats, Capital E (2003)

[9] "High performance buildings - LEED and Energy Star" Colorado Springs utilities (2008)

[10] Sustainable Project Rating Tool (SPiRiT) version 1.4.1Richard Schneider and Donald F. Fournier - 2004

[11] Sustainable Project Rating Tool (SPiRiT) USGBC 4th Annual 2001 Membership Summit Green Building University - Richard Schneider - 2001

[12] BCA Green Mark Certification Standard for Existing Buildings (GM Version 3.0) 2016

[13] "Building rating systems (certification programs) a comparison of key programs" Air Quality Sciences (2009)

[14] BOMA BESt and LEED - Amy Vandervelde and Wendy Waters 2010

[15] BOMA BESt and LEED EBOM comparison, International Facility Management Association - James Furlong - 2012

[16] Pearl Building Rating Systems "Design and Construction" Version 1.0 (2010)

[17] "GSAS Building Typologies Design Guidelines" - 2015

[18] Green Building Council of Australia - The Value of Green Star - A Decade of Environmental Benefits - 2013

[19] "Evaluating Environmental Performance of Vernacular Architecture through CABSEE” Shuzo Murakami -2008

[20] Technical manual green star SA existing building performance pilot rev.1 - 2014 